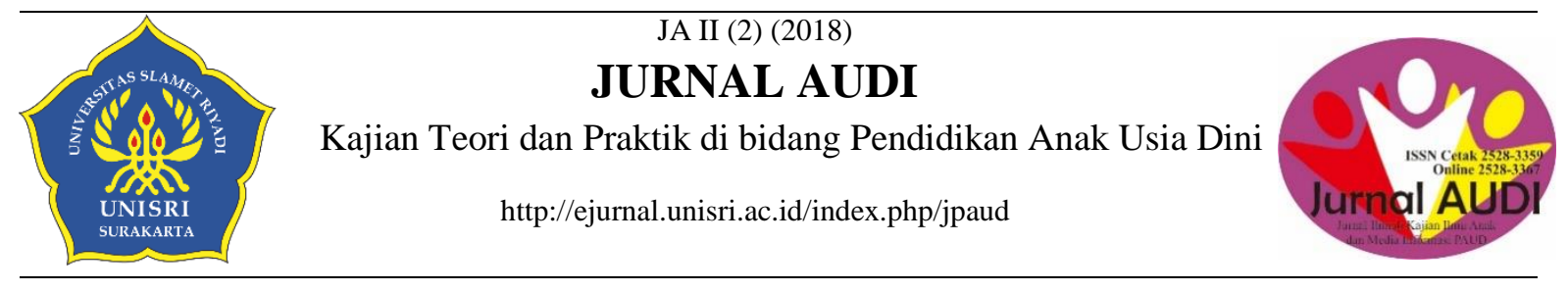

\title{
MENINGKATKAN MOTORIK HALUS ANAK MELALUI KEGIATAN MENGANYAM PADA ANAK KELOMPOK B USIA 5-6 TAHUN
}

Anggita Febriana $^{1}$, Lydia Ersta Kusumaningtyas ${ }^{2}$ Universitas Slamet Riyadi

\section{Info Artikel}

Sejarah Artikel:

Diterima Agustus 2017

Disetujui November

2017

Dipublikasikan

Desember 2017

\section{Keywords:}

Smooth Motorik, weaving activities, children aged 5 to 6 years

\begin{abstract}
Abstrak
Tujuan yang dicapai dalam penelitian ini adalah untuk meningkatkan motorik halus anak melalui kegiatan menganyam pada anak kelompok B usia 5-6 tahun di Kelompok Bermain Anak Bintang Ceria Jumantono. Penelitian ini merupakan Penelitian Tindakan Kelas (PTK). Penelitian ini populasinya adalah anak usia 5 sampai dengan 6 tahun di Kelompok Bermain Anak Bintang Ceria Jumantono yang berjumlah 20 anak yang terdiri dari 11 anak laki-laki dan 9 anak perempuan. Teknik pengumpulan data yang digunakan dalam penelitian ini melalui observasi dan dokumentasi. Teknik analisis data yang digunakan yaitu teknik analisis kuantitatif dan teknik analisis deskriptif kualitatif. Hasil penelitian menunjukkan bahwa kegiatan menganyam dapat meningkatkan motorik halus anak. Hal ini dibuktikan dari hasil observasi sebelum tindakan, anak yang mendapat kriteria berkembang sangat baik (BSB) diperoleh rata-rata persentase 25\% atau 5 anak, pada siklus I mengalami peningkatan sebesar 35\% atau 7 anakdan pada pelaksanaan siklus II meningkat sebesar 90\% atau 18 anak. Penelitian ini dihentikan karena sudah memenuhi indikator keberhasilan penelitian yaitu $80 \%$. Pada siklus I kegiatan menganyam dilakukan dengan menggunakan kertas dengan model anyaman tunggal, sedangkan pada siklus II kegiatan menganyam dilakukan dengan menggunakan daun pisang dengan model anyaman tunggal.
\end{abstract}

Abstract

The objective of this research was to improve fine motor of the students by weaving activity to the students of Class B aged 5 to 6 at Bintang Ceria Playgroup Ju manono.The study was a classroom action research. The population was the students aged 5 to 6 at Bintang Ceria Playgroup Jumantono which consisted of 20 kids, 11 male and 9 female. To collect the data observation and documenation were used. While to analize the data, quantitative and descriptive qualitative techniques were employed.Based on the sudy, it was found that weaving improved the students fine motor. It was seen from the result of observation before action. The students who belonged to very well developed criteria was $25 \%$ or five students. In cycle I, it became $35 \%$ or seven students. In cycle II, it significantly improved to be $90 \%$ or eighteen students. In cycle I, the students used paper in weaving activity with singgle webbing model. While in cycle II, the students used banana leaf in weaving activity with singgle webbing model.

Keywords: Smooth Motorik, weaving activities, children aged 5 to 6 years

(C) 2018 FKIP Universitas Slamet Riyadi

$\begin{array}{rr}\square \text { Alamat korespondensi: J1 Sumpah Pemuda No } & \text { ISSN 2528-3359 (Print) } \\ \text { 18, Kadipiro, Surakarta } & \text { ISSN2528-3367 (Online) }\end{array}$

E-mail: anggitafebriana9@gmail.com 
Anggita Febriana, Meningkatkan Motorik Halus Anak Melalui Kegiatan Menganyam Pada Anak Kelompok B Usia 5-6 Tahun

\section{Pendahuluan}

Pendidikan anak usia dini sangat diperlukan untuk kesiapan anak dalam memasuki jenjang pendidikan selanjutnya. Undang-undang Nomor 20 tahun 2003 tentang Sistem Pendidikan Nasional Pasal 1 ayat 4 menjelaskan bahwa Pendidikan Anak Usia Dini adalah suatu upaya pembinaan yang ditujukan kepada anak sejak lahir sampai dengan usia 6 tahun yang dilakukan melalui pemberian rangsangan pendidikan untuk membantu pertumbuhan dan perkembangan jasmani dan rohani anak agar memiliki kesiapan memasuki jenjang pendidikan selanjutnya.

Makmun Khairani menyatakan bahwa perkembangan motorik halus adalah perkembangan otot-otot tangan pada anak untuk melakukan beberapa gerakan yang membutuhkan koordinasi seperti meremas kertas, memegang benda-benda tertentu, menulis, menyobek kertas atau kegiatan apapun yang memerlukan ketrampilan tangan. Melatih perkembangan motorik halus anak sangat penting, karena gerakan motorik halus inilah yang nantinya akan mempermudah setiap aktivitas yang dilakukan oleh anak. Jika anak belum bisa mengembang kan kemampuan motorik halus nya dengan baik, maka anak juga akan mengalami kesulitan dalam mengerjakan kegiatan yang berhubungan dengan ketrampilan tangan, bahkan anak juga mengalami kesulitan untuk memakai baju dan sepatunya sendiri.Kegiatan motorik halus yang biasanya dilakukan dalam pembelajaran PAUD yaitu mewarnai, menggunting, menempel, mengecap, melukis dengan jari, meroce dan lain-lain. Kegiatan-kegiatan yang mencakup pemanfaatan bahan alam sekitar lingkungan kita masih belum maksimal, terutama dalam kegiatan menganyam. Dalam pembelajaran motorik halus tidak hanya belajar melakukan kegiatan yang membutuhkan ketrampilan tangan, tetapi juga belajar mengingat, mengamati dan meniru. Berdasarkan hasil observasi yang dilakukan terhadap perkembangan motorik halus pada anak kelompok B Usia 5-6 Tahun Kelompok
Bermain Anak Bintang Ceria Jumantono Tahun Pelajaran 2016/2017 menunjukkan bahwa perkembangan motorik halus yang dimiliki anak masih kurang berkembang. Terlihat dalam kegiatan mewarnai, terdapat beberapa anak yang cara mewarnai nya masih kaku dan tercoret-coret, sehingga hasil mewarnai nya terlihat kurang rapi, selain itu ketika belajar menyobek kertas anak masih kesulitan dalam menyobek menjadi bagian yang kecil-kecil, sehingga sobekan kertas cenderung menjadi besarbesar dan kurang rapi serta pada saat kegiatan membuat lingkaran masih ada yang berbentuk kotak yang dilakukan oleh guru.

Pengembangan motorik halus anak sangat penting, sebab dalam mengembangkan motorik halus anak dapat memfungsikan dan menstimulasi otot-otot kecil anak untuk melakukan gerakangerakan tangan, mengkoordinasikan gerakan mata dan tangan. Salah satu kegiatan yang dapat meningkatkan motorik halus anak yaitu melalui kegiatan menganyam, karena kegiatan menganyam dapat melatih konsentrasi anak, melatih koordinasi mata dan tangan,melatih ketelitian dan diharapkan dapat menarik perhatian dan minat siswa, selain itu kegiatan menganyam belum diterapkan secara optimal, sehingga peneliti merasa untuk melakukan penelitian tentang mengembangkan motorik halus pada anak kelompok B Usia 5-6 Tahun di Kelompok Bermain Anak Bintang Ceria Jumantono tahun pelajaran 2016/2017 melalui kegiatan menganyam.

Tujuan kegiatan menganyam ini adalah untuk meningkatkan motorik halus anak di kelompok B Usia 5-6 Tahun Kelompok Bermain Anak Bintang Ceria Jumantono tahun pelajaran 2016/2017. Dengan kegiatan ini di harapkan motorik anak dapat berkembang dengan baik. Berdasarkan latar belakang masalah diatas, peneliti mengambil judul “ Meningkatkan Motorik Halus Anak Melalui Kegiatan Menganyam Pada Anak Kelompok B Usia 5-6 Tahun Kelompok Bermain Anak Bintang Ceria Jumantono Tahun Pelajaran 2016/2017.“ 
Anggita Febriana, Meningkatkan Motorik Halus Anak Melalui Kegiatan Menganyam Pada Anak Kelompok B Usia 5-6 Tahun

\section{Identifikasi Masalah}

Berdasarkan latar belakang masalah diatas, dapat diidentifikasi kan masalah di Kelompok B Usia 5-6 Tahun Di Kelompok Bermain Anak Bintang Ceria Jumantono tahun pelajaran 2016/2017 adalah :

1. Kemampuan motorik halus anak masih kurang berkembang

2. Teknik-teknik yang digunakan guru dalam mengembangkan motorik halus masih monoton dan guru hanya menggunakan majalah saja.

\section{Pembatasan Masalah}

Meningkatkan motorik halus anak melalui kegiatan menganyam pada anak kelompok B Usia 5-6 Tahun di Kelompok Bermain Anak Bintang Ceria Jumantono tahun pelajaran 2016/2017.

\section{Rumusan Masalah}

Berdasarkan uraian latar belakang masalah diatas, maka rumusan masalah dalam penelitian ini adalah:"Bagaimana meningkatkan motorik halus anak melalui kegiatan menganyam pada anak kelompok B Usia 5-6 Tahun Di Kelompok Bermain Anak Bintang Ceria Jumantono tahun pelajaran 2016/2017 ?"

\section{Tujuan Penelitian}

Berdasarkan latar belakang dan rumusan masalah diatas, maka tujuan dari penelitian ini adalah untuk mengetahui bagaimana meningkatkan motorik halus anak melalui kegiatan menganyam pada anak kelompok B Usia 5-6 Tahun Di Kelompok Bermain Anak Bintang Ceria Jumantono tahun pelajaran 2016/2017.

\section{Manfaat Penelitian}

Untuk meningkatkan pengetahuan guru dalam meningkatkan perkembangan motorik halus anak.

\section{Landasan Teori}

a. Pengertian Perkembangan Motorik

Menurut

Suyadi

(2010:67)

Perkembangan motorik adalah

perkembangan gerak melalui kegiatan pusat syaraf,urat syaraf dan otot yang terkoordinasi. Gerak tersebut berasal dari pekembangan refleks dan kegiatan yang telah ada sejak lahir. Menurut Depdiknas (2012:6) Perkembangan motorik adalah segala sesuatu yang ada hubungannya dengan gerakangerakan tubuh.

b. Fungsi Perkembangan Motorik

Hurlock (dalam Depdiknas 2012:20) fungsi perkembangan motorik yaitu:

1. Melalui ketrampilan motorik, anak dapat mengibur dirinya dan dapat memperoleh perasaan senang. Contohnya seperti anak senang ketika dia bisa belajar menulis.

2. Melalui ketrampilan motorik, anak dapat beranjak dari kondisi tidak berdaya kedalam kondisi independent, dimana anak dapat bergerak dari satu tempat ketempat lain.

c. Pengertian Motorik Halus

Menurut Christiana Hari Soetjiningsih (2012:187) menyatakan bahwa pengertian motorik halus adalah kemampuan yang melibatkan koordinasi mata dan tangan untuk melakukan gerakan-gerakan secara halus. Mansur (2011:23) menyatakan bahwa pengertian motorik halus adalah perkembangan otot halus dan fungsinya untuk melakukan gerakan-gerakan yang menggunakan ketrampilan tangan. Suyadi (2010:69) menyatakan bahwa pengertian motorik halus adalah pengkoordinasian gerak tubuh yang melibatkan otot dan syaraf yang jauh lebih kecil yang membutuhkan koordinasi mata dan tangan.

d. Tujuan Pengembangan Motorik Halus

Tujuan pengembangan motorik halus untuk anak usia dini (Nofra Candra Lovia,2012), yaitu:

(1) Sebagai alat untuk pengembangan ketrampilan kedua tangan

(2) Sebagai alat untuk pengembangan koordinasi mata dan tangan

(3) Sebagai alat untuk melatih penguasaan emosi anak

e. Pengertian Menganyam

Menurut Hajar Pamadhi (2012:38) menganyam adalah kerajinan tradisional yang dilakukan dengan cara menyusupkan bagian-bagian pita anyaman secara bergantian. Disamping banyak kegunaannya juga mempunyai unsur pendidikan, maka sejak usia dini kerajinan menganyam ini sudah diajarkan untuk melatih motorik halus anak.

f. Manfaat Menganyam Untuk Anak Usia Dini 
Anggita Febriana, Meningkatkan Motorik Halus Anak Melalui Kegiatan Menganyam Pada

Anak Kelompok B Usia 5-6 Tahun

Menurut Hajar Pamadhi (2012:39) manfaat menganyam bagi anak usia dini yaitu :

(1) Mengembangkan motorik halus anak

(2) Mengembangkan koordinasi mata dan tangan untuk melatih konsentrasi Anak

\section{METODE PENELITIAN}

\section{a. Tempat dan Waktu}

1. Tempat penelitian

Penelitian tindakan kelas ini dilakukan di

Kelompok Bermain Anak Bintang Ceria Jumantono tahun pelajaran 2016/2017. Alasan peneliti mengambil tempat ini yaitu peneliti merupakan salah satu tenaga pengajar di sekolah ini, sehingga peneliti lebih mudah dalam melakukan penelitian.

2. Waktu Penelitian

Penelitian tindakan kelas ini dilakukan pada pertengahan bulan Mei sampai dengan bulan Juni 2017.

\section{b. Subjek Penelitian}

Subjek dalam penelitian ini adalah anak kelompok B Usia 5-6 Tahun di Kelompok Bermain Anak Bintang Ceria Jumantono yang terdiri dari 20 anak.

\section{c. Prosedur Penelitian}

Menurut Suharsimi Arikunto (2006:16) prosedur penelitian tindakan kelas terbagi menjadi empat tahapan yaitu tahap perencanaan, tahap pelaksanaan, tahap observasi dan tahap refleksi

\section{d. Data dan Sumber Data}

Data yang dikumpulkan berupa informasi tentang meningkatnya motorik halus anak pada kelompok B Usia 5-6 Tahun di Kelompok Bermain Anak Bintang Ceria Jumantono. Data yang dikumpulkan diperoleh dari informan yaitu guru atau teman sejawat, tempat dan peristiwa yaitu di Kelompok Bermain Anak Bintang Ceria Jumantono. Data berupa nama anak, kemampuan motorik halus anak dan foto kegiatan proses belajar mengajar.

\section{e. Teknik Pengumpulan Data}

Teknik pengumpulan data yang digunakan dalam penelitian ini adalah :

\section{Observasi}

Observasi adalah kegiatan pengamatan yang di lakukan secara langsung untuk mengamati proses pembelajaran menganyam untuk meningkatkan motorik halus anak di Kelompok Bermain Anak Bintang Ceria Jumantono tahun pelajaran 2016/2017.

2. Dokumentasi

Dokumentasi digunakan untuk memberikan gambaran nyata mengenai kegiatan anak yang diperoleh dengan cara mengambil foto anak pada saat proses pembelajaran berlangsung. Dokumentasi berupa foto hasil kegiatan anak pada waktu kegiatan menganyam di Kelompok Bermain Anak Bintang Ceria Jumantono Tahun Pelajaran 2016/2017.

\section{f. Validitas Data}

Data yang ada harus benar-benar valid sesuai dengan data yang tertulis dalam lembar observasi. Setiap informasi yang tertera dalam lembar observasi merupakan informasi yang paling penting dalam penelitian ini, sehingga informasi yang di dapat harus akurat. Validitas data yang di gunakan dalam penelitian meningkatkan motorik halus anak melalui kegiatan menganyam pada anak kelompok B Usia 56 tahun di Kelompok Bermain Anak Bintang Ceria yaitu dengan menggunakan triangulasi.

\section{g. Teknik Analisis Data}

Setelah data diperoleh dan dikumpulkan, maka langkah selanjutnya yaitu menganalisis data. Menurut Sarwiji Suwandi (2009:61) analisis data penelitian ada dua macam yaitu analisis deskriptif komparatif atau statistik deskriptif komparatif yang digunakan untuk deskriptif kuantitatif dan teknik analisis kualitatif

Menurut Nar Heryanto ( 2012 : 30 ) Rata-rata dapat dinotasikan dengan $\mathrm{X}$, rumus yang digunakan yaitu:

$$
\mathrm{X}=\frac{\mathrm{N}}{\mathrm{n}} \mathrm{x} 100 \%
$$

Keterangan :

$X$ : Rata - rata (\%)

$\mathrm{N}$ : Jumlah anak yang mendapat kriteria

$\mathrm{n}$ : Jumlah siswa keseluruhan

h. Indikator Keberhasilan

Keberhasilan dalam penelitian ini ditandai dengan adanya perubahan ke arah yang lebih baik. Keberhasilan akan terlihat apabila hasil dalam kegiatan menganyam terjadi peningkatan. Kriteria keberhasilan 
Anggita Febriana, Meningkatkan Motorik Halus Anak Melalui Kegiatan Menganyam Pada Anak Kelompok B Usia 5-6 Tahun

dalam penelitian ini adalah apabila $80 \%$ dari jumlah anak secara keseluruhan yang mendapat nilai baik ( berkembang sangat baik )

\section{HASIL DAN PEMBAHASAN}

1. Siklus 1

Pelaksanaan siklus 1 dilakukan sebanyak

2 kali pertemuan yaitu pada hari Rabu tanggal 10 Mei 2017 dan hari Jum'at tanggal 12 Mei 2017.

1) Siklus 1

a. Perencanaan Siklus 1

Dalam tahap perencanaan, peneliti membuat perencanaan pembelajaran yang akan dilaksanakan pada siklus 1 pertemuan 1 Peneliti membuat Rencana Kegiatan Pembelajaran Harian (RKH), yang didiskusikan bersama guru kelas terlebih dahulu sebagai kolaborator. Langkah selanjutnya peneliti menyiapkan media pembelajaran yang akan di gunakan untuk menganyam yaitu lungsi dan pakan,lembar observasi yang akan di gunakan dan foto yang di gunakan untuk mendokumentasi kan setiap hasil kegiatan.

b. Pelaksanaan Siklus 1

Tahap pelaksanaan pada siklus 1 dilaksanakan pada hari Rabu tanggal 10 Mei 2017 dengan menggunakan kegiatan pembelajaran menganyam, tujuan dari kegiatan menganyam yaitu untuk.

2) Siklus II

Pelaksanaan siklus II dilaksanakan dalam dua kali pertemuan, yaitu pada hari Selasa tanggal 16 Mei 2017 dan Selasa tanggal 23 Mei 2017

Dalam tahap perencanaan, hal-hal yang dilakukan sebagai berikut:

1. Mempersiapkan Rencana Kegiatan Harian sesuai dengan Rencana Kegiatan Harian di Kelompok Bermain Anak Bintang Ceria seperti biasanya.

2. Mempersiapkan media pembelajar an yang akan digunakan unuk menganyam.

3. Mempersiapkan lembar observasi yang akan digunakan untuk mengamati hasil kegiatan yang dilakukan oleh anak.

\section{Pembahasan Hasil Penelitian}

Penelitian yang dilakukan oleh peneliti merupakan penelitian tindakan kelas yang terdiri dari 2 siklus, setiap siklus terdiri dari perencanaan, pelaksanaan, observasi dan refleksi. Setiap siklus terdiri dari dua kali pertemuan. Siklus II merupakan langkah yang dilakukan untuk mengatasi masalah yang muncul pada siklus I, sehingga diperoleh hasil yang terus meningkat pada setiap pertemuan yang dilaksanakan, sehingga mencapai target yang diharapkan. Hasil yang diperoleh dalam siklus ini di dapat dari data hasil observasi. Data hasil observasi ini digunakan untuk mengetahui hasil peningkatan motorik halus anak.Kemampuan motorik halus dapat dikembangkan dengan berbagai cara, salah satunya yaitu dengan kegiatan menganyam. Menganyam adalah kegiatan menyusupkan pakan kedalam lungsi untuk melatih kesabaran anak, ketelitian, mengkoordinasikan mata dan tangan untuk melakukan gerakan yang rumit, serta dapat melatih konsentrasi anak dalam memasukkan pakan kedalam lungsi. Dengan demikian menganyam dapat meningkatkan motorik halus anak.

Berdasarkan hasil penelitian dapat disimpulkan bahwa perkembangan motorik halus anak di Kelompok Bermain Anak Bintang Ceria dapat ditingkatkan melalui kegiatan menganyam. motorik halus anak melalui kegiatan menganyam dapat dilihat dari hasil observasi sebelum tindakan diperoleh persentase motorik halus anak sebesar 25\% dengan kriteria berkembang sangat baik, mulai berkembang dengan persentase sebesar $27 \%$ dan belum berkembang dengan persentase sebesar $48 \%$. Setelah diberi tindakan ada peningkatan pada siklus I dengan kriteria berkembang sangat baik sebesar 35\%, kriteria mulai berkembang sebesar $65 \%$ dan kriteria belum berkembang sebesar 0\%. Pada siklus II kriteria berkembang sangat baik meningkat sebesar $90 \%$, kriteria mulai berkembang sebesar $10 \%$ dan kriteria belum berkembang sebesar $0 \%$ 
Anggita Febriana, Meningkatkan Motorik Halus Anak Melalui Kegiatan Menganyam Pada Anak Kelompok B Usia 5-6 Tahun

Rekapitulasi Kemampuan Perkembangan Motorik Halus Anak Melalui Kegiatan Menganyam Sebelum Tindakan, Siklus I dan Siklus II

\begin{tabular}{|l|l|c|c|c|}
\hline \multirow{2}{*}{ No } & \multicolumn{1}{|c|}{ Krieria } & \multicolumn{3}{|c|}{ Hasil } \\
\cline { 3 - 5 } & & Kondisi Awal & Siklus I & Siklus II \\
\hline 1. & $\begin{array}{l}\text { Belum } \\
\text { Berkembang }\end{array}$ & $48 \%$ & 0 & 0 \\
\hline 2. & $\begin{array}{l}\text { Mulai } \\
\text { Berkembang }\end{array}$ & $27 \%$ & $65 \%$ & $10 \%$ \\
\hline 3. & $\begin{array}{l}\text { Berkembang } \\
\text { Sangat Baik }\end{array}$ & $25 \%$ & $35 \%$ & $90 \%$ \\
\hline
\end{tabular}

\section{SIMPULAN}

Berdasarkan hasil pembahasan penelitian dapat disimpulkan bahwa kemampuan motorik halus anak usia 5-6 tahun di Kelompok Bermain Anak Bintang Ceria Jumantono dapat di tingkatkan melalui kegiatan menganyam. Hal tersebut dapat dilihat dari persentase kemampuan motorik halus anak sebelum tindakan sebesar $25 \%$ dan pada pelaksanaan siklus II meningkat menjadi $90 \%$.

Proses dalam kegiatan menganyam dapat diterapkan pada anak usia 5-6 tahun. Melalui kegiatan menganyam dapat meningkatkan motorik halus anak dengan melaih ketelitian anak, kecermatan dan melatih kesabaran anak serta anak dapat mengkoordinasi kan mata dan tangan untuk melakukan gerakan yang rumit.

\section{DAFTAR PUSTAKA}

Ahmad Susanto. 2012. Perkembangan Anak Usia Dini. Jakarta: Kencana Prenada Media Group.

Christina Hari Soetjiningsih. 2012. Perkembangan Anak. Jakarta: Prenada.

Depdiknas. 2007. Pedoman Pembelajaran

Bidang Pengembangan Fisik MotorikAnak Taman Kanakkanak. Jakarta: Direktorat Pembinaan TK dan SD.

Hajar Pamadhi. 2012. Seni Ketrampilan Anak. Tangerang Selatan: Universitas Terbuka.

Makmun Khairani. 2013. Psikologi Perkembangan.Yogyakarta: Presindo.
Mansur. 2011. Pendidikan Anak Usia Dini dalam Islam.Yogyakarta: Pustaka Pelajar.

Maulina Bouchard. Prinsip - prinsip Motorik Halus Anak dalam Depdiknas. 2012. Jakarta: Dirjen PAUD

Nar Heryanto.2012. Statistika Pendidikan. Universitas Terbuka

Nur Hidayah.2012. Meningkatkan Motorik Halus Anak Melalui Kegiatan Menganyam Pada Anak Kelompok A di TK PKK Mulyorini Surobayan.

Nofra Candra Lovia. 2012. Pengembangan Motorik Halus Anak.Diambil dari:http://nofracandralovia.blo gspot.com/2012/12/2017penge mbangan-motorik-halusanak. html. Diakses tanggal 15 Februari 2017.

Permendikbud No 137. 2014. Standar Nasional Pendidikan Anak Usia Dini. Jawa Tengah: Dinas Pendidikan. 